UDC: $636.2 / .3(497.11) \quad 636.2 / .3(497.6)$

636.2/.3(497.17)

COBISS.SR-ID: 227894284

Original research paper

Acta Agriculturae Serbica, Vol. XXI, 41 (2016); 57-63

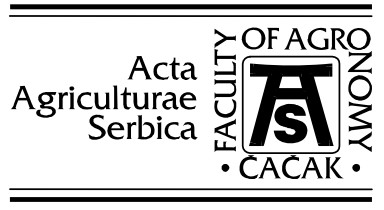

\title{
Analysis of the total number of some ruminants in Bosnia and Herzegovina, Serbia and Macedonia
}

\author{
Gjoko Bunevski ${ }^{1}$, Marko Lazic ${ }^{2}$, Jelena Nikitovic ${ }^{3}$ \\ ${ }^{1}$ Ss. Cyril and Methodius University of Skopje, Faculty of Agriculture Sciences \\ and Food, Blvd. Aleksandar Makedonski nn., P.O. Box 297, 1000 Skopje, \\ Republic of Macedonia (e-mail: bunevski@gmail.com) \\ ${ }^{2}$ University of Kragujevac, Faculty of Agronomy, Cara Dusana 34, 32000 \\ Cacak, Republic of Serbia (PhD student,e-mail:msc.lazic@gmail.com) \\ ${ }^{3}$ University of Banja Luka, Genetic Resources Institute, Bulevar vojvode Petra \\ Bojovica 1A, 78000 Banja Luka, Republic of Srpska, Bosnia and Herzegovina \\ (e-mail:jelena.nikitovic@griunibl.rs.ba)
}

\begin{abstract}
The aim of this paper is to present the total number of some ruminants in recent years (from 2007 to 2014) in Bosnia and Herzegovina, Serbia and Macedonia. The analysis of the total number of cattle, goats and sheep was based on the information available on the FAOSTAT statistical database website. To perform statistical analysis, we used the base indices which show the percentage change between the annual and average numbers of ruminants in the analyzed period. The comparison of the average numbers of cattle, goats and sheep in this period revealed that these ruminants were the most numerous in Serbia. The least significant difference test indicated that the differences between Macedonia and Bosnia and Herzegovina in the total number of goats in 2007-2014 were statistically non-significant $(p>0.001)$.
\end{abstract}

Key words: basic index, cattle, goats, sheep.

Received: 14.06.2016; Accepted: 16.11.2016 


\section{Introduction}

Based on FAOSTAT website data on the global ruminant population in 2014, the highest numbers of cattle were located in America (34.4\%), while goats $(58.2 \%)$ and sheep (45.4\%) predominated in Asia.

Compared to the other continents, Europe ranked third in the number of sheep $(10.8 \%)$ and fourth in the numbers of cattle $(8.3 \%)$ and goats $(1.7 \%)$. However, special attention should be paid to the total number of ruminants in Europe, which amounted to 253829414 cattle in 1985, 297768778 sheep in 1989 and 22210391 goats in 1991. In 2014, Europe had a total of 130291237 sheep, 122711099 cattle and 16799674 goats, showing a steadily declining tendency (Lazic et al., 2016b). The main objectives in livestock production are based on the prevention of decrease in the total number of domestic animals,

followed by increasing productivity through modification and improvement of the breed structure, as well as the preservation of genetic reserves of domestic animals and biological diversity in livestock (Bunevski et al., 2016; Nikitovic et al., 2016a). Thanks to the development of the digestive tract and microflora of the rumen, ruminants are capable of transforming different types of plant nutrients into high-value products of animal origin. Many local authors studied ruminants, particularly cattle (Bunevski et al., 2016; Lazic and Spasic, 2015; Lazic et al., 2015, 2016a, 2016c; Nikitovic et al., 2016b).

The aim of this paper is to present an analysis of the total number of cattle, goats and sheep in Bosnia and Herzegovina, Serbia and Macedonia from 2007 to 2014.

\section{Materials and methods}

The analysis presents the total number of head of some ruminants based on the data available on the FAOSTAT statistical database website (faostat3.fao.org, 03/06/16). The study covered the total number of head of cattle, goats and sheep in Bosnia and Herzegovina, Serbia and Macedonia from 2007 to 2014.

To perform statistical analysis, the total number of head of cattle, goats and sheep, the arithmetic mean and standard deviation were used, while the least significant difference $(\alpha=0.001)$ test was used to assess the significance of differences between Bosnia and Herzegovina, Serbia and Macedonia. Indices showing the percentage change between the annual and average numbers of ruminants in the analyzed period were also used. Similar analyses were presented by other authors (Lazic et al., 2016b) using a different index base. 


\section{Results and Discussion}

The results on the average value and standard deviation of the total number of cattle, goats and sheep in 2007-2014, as well as the significance of differences between Bosnia and Herzegovina, Serbia and Macedonia are shown in Figure 1.

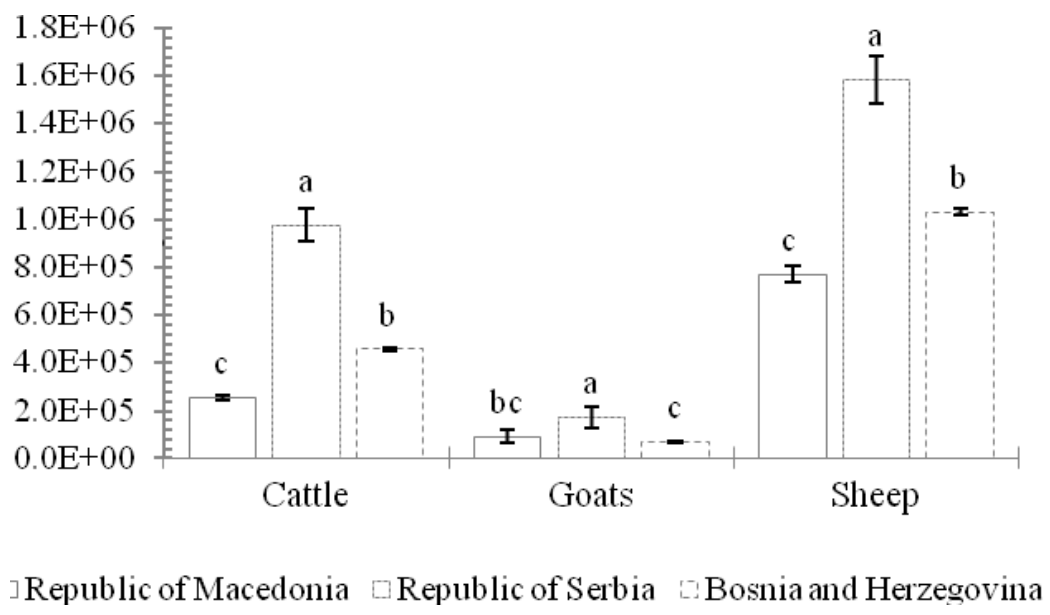

Figure 1. Average \pm standard deviation of the total number of ruminants in

Bosnia and Herzegovina, Serbia and Macedonia (from 2007 to 2014)

The different letters denote significant differences among countries at $\alpha=0.001$

As shown, the average number of cattle, goats and sheep from 2007 to 2014 in Bosnia and Herzegovina, Serbia and Macedonia (Figure 1) indicates that the studied ruminants were the most numerous in Serbia. However, in recent years, there has been a continuous decline in the total of number of cattle in Serbia (Lazic et al., 2016b), as also recorded throughout Europe. As regards small ruminants, Serbia is followed by Macedonia in the total number of goats, and by Bosnia and Herzegovina in the total number of sheep. With regard to the result obtained, the least significant difference test indicates that the differences between Macedonia and Bosnia and Herzegovina in the total number of goats in the 2007-2014 period were statistically non-significant $(p>0.001)$, while the difference for other ruminants between the tested countries was statistically very significant $(p \leq 0.001)$.

Figure 2. shows the percentage change in base indices for the numerical data on cattle, goats and sheep during 2007 to 2014 in Bosnia and Herzegovina, Serbia and Macedonia. 


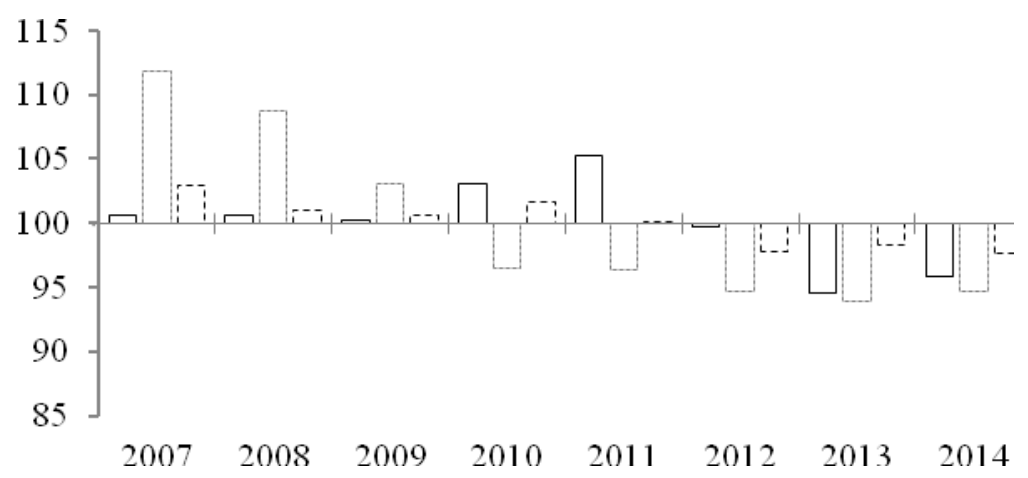

(a)

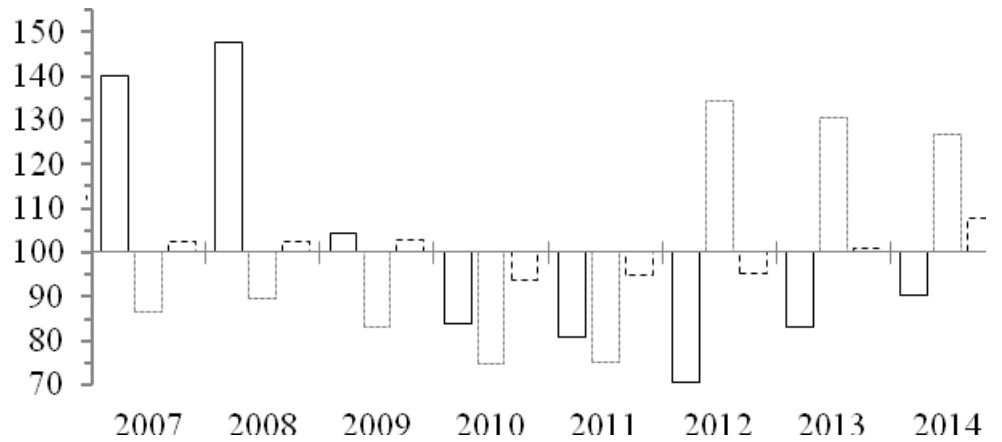

(b)

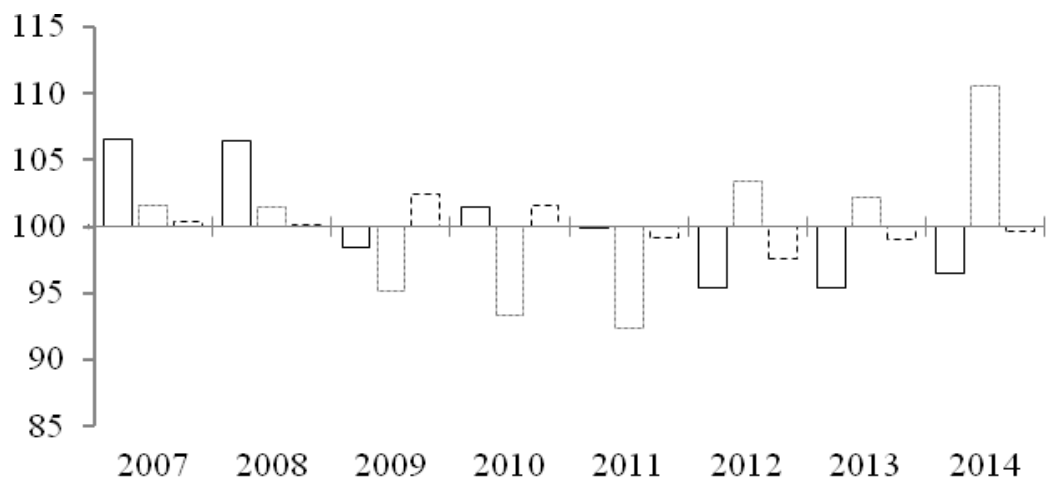

$\square$ Republic of Macedonia $\square$ Republic of Serbia $\quad$ Bosnia and Herzegovina (c)

Figure 2. Analysis of the basic index (\%) of the total number of cattle (a), goats (b) and sheep (c) during 2007 to 2014. 
During the period, the total number of cattle was highest in Serbia in 2007, showing an increase by $11.85 \%$ relative to the base, followed by Bosnia and Herzegovina, also in 2007, with its $2.91 \%$ increase, whereas the highest number of cattle in Macedonia was recorded in 2011 as a $5.27 \%$ increase relative to the base. Apart from these data (Figure 2a), the minimum number of cattle was recorded in Macedonia in 2013 (94.57\% of the base), followed by Bosnia and Herzegovina in 2014 (97.63\% of the base) and Serbia in 2013 (93.95\% of the base). When comparing the total number of cattle relative to the basic index for the period 2006 to 2014 in the Republic of Serbia with the current number of 956 268 head (22 December 2015), some authors (Lazic et al., 2016b) observed an increase in the total number of cattle, which noticeably decreased during 20102014 (relative to the previous 2006 - 2009 period). The total number of goats in 2007-2014 (Figure 2b) was highest in Serbia in 2012, showing a 34.37\% increase relative to the base, followed by Macedonia in 2008 (a $47.40 \%$ increase), whereas in Bosnia and Herzegovina the highest number of goats was recorded in 2014 (an increase by $7.73 \%$ relative to the base). In contrast, the minimum number of goats was recorded in Bosnia and Herzegovina (93.54\% of the base) and Serbia (74.61\% of the base) during 2010, whereas the lowest number of goats in Macedonia was recorded in 2012 (70.46\% of the base). As for sheep (Figure 2c), the lowest number in Macedonia was recorded in 2013 (95.37\% of the base), followed by Bosnia and Herzegovina in 2012 (97.59\% of the base), while in Serbia the lowest number of sheep was recorded in 2011 (92.35\% of the base). However, the highest number of sheep in 2007-2014 was in Serbia in 2014 , which was a $10.55 \%$ increase relative to the base, followed by Bosnia and Herzegovina in 2009 (an increase by $2.47 \%$ ), while in Macedonia the highest number of sheep was recorded in 2007 (a $6.53 \%$ increase relative to the base). Relative to the ten-year average (2005-2014) in the Republic of Serbia, the total number of cattle decreased by $8.1 \%$ and that of goats by $16.3 \%$, while the number of sheep increased by $13.4 \%$ (www.pks.rs; 03/06/16).

\section{Conclusion}

The comparison of the average numbers of cattle, goats and sheep in the analyzed period suggests that these ruminants are the most numerous in Serbia. As for small ruminants, the highest number of goats, after Serbia, was recorded in Macedonia, and that of sheep in Bosnia and Herzegovina. The least significant difference test indicated that the differences in the average number of goats for the 2007-2014 period between Macedonia and Bosnia and Herzegovina were statistically non-significant $(p>0.001)$, while the difference for other ruminants between the tested countries was statistically very significant $(p \leq 0.001)$. The total number of cattle, goats and sheep in 2007-2014 showed the highest deviation from the average number of ruminants in Serbia. Considering that animal husbandry deals with breeding domestic animals for the purpose of 
obtaining various irreplaceable animal products, special attention should be given to this branch of agriculture, primarily in terms of the total number of farmed animals.

\section{Acknowledgements:}

We wish to express our gratitude to $\mathrm{PhD}$ Goran S. Markovic, Associate Professor, Faculty of Agronomy, Cacak, who brought the authors together and suggested an idea, which was implemented through this analysis.

\section{References}

Bunevski, Gj., D. Kocevski, V. Dzabirski, K. Porcu, Z. Saltamarski (2016): Creating a gene bank for Busha cattle in the R. of Macedonia. XXI Symposium on Biotechnology with international participation, 1112 March, Faculty of Agronomy, Cacak, Republic of Serbia, Vol. 21 (24): 559-564.

Food and Agriculture Organization of the United Nations (FAOSTAT): http://faostat3.fao.org/browse/Q/QA/E (access: 03/06/2016)

Lazic, M. and Z. Spasic (2015): Linear regression and correlation of reproductive traits in population of Holstein-Friesian cattle. Ninth Conference of Agronomy Students with international participation, oral presentation, 26-28 August, Faculty of Agronomy, Cacak, Republic of Serbia, Vol. 9 (9): 56-64.

Lazic, M., Z. Spasic, D. Grcak, Z. Ilic, B. Milosevic and S. Rakonjac (2015): Comparison of linear type traits of daughters of Simmental bulls. Acta Agriculturae Serbica. 20: 99-106.

Lazic, M., Z. Spasic, M. Petrovic, Z. Ilic, R. Rajcic (2016a): Analysis of correlation between exterior properties of Simmental cows. Fifth International Symposium on Agricultural Sciences "AgroReS 2016", poster presentation - ASP17, February 29-March 3, Banja Luka, Bosnia and Herzegovina. Book of Abstracts, 198.

Lazic, M., M. Petrovic, Z. Spasic, B. Radovic, R. Rajcic (2016b): Analiza ukupnog brojnog stanja goveda u Republici Srbiji. XXI Symposium on Biotechnology with international participation, 11-12 March, Faculty of Agronomy, Cacak, Republic of Serbia, Vol. 21 (24): 513-517.

Nikitovic, J., J. Sjencic, G. Djuric (2016a): Analysis of legislation in the field of conservation of animal genetic resources of the Republic of Srpska. Fifth International Symposium on Agricultural Sciences "AgroReS 2016", oral presentation - SMNRO7, February 29 - March 3, Banja Luka, Bosnia and Herzegovina. Book of Abstracts, 106.

Nikitovic, J., N. Pracic, B. Bosancic (2016b): Koncentracija Ca, P i Mg u serumu kod krava simentalske rase sa razlicitih geografskih podrucija. $X X I$ Symposium on Biotechnology with international participation, 11-12 March, Faculty of Agronomy, Cacak, Republic of Serbia, Vol. 21 (24): 499-504.

Privredna komora Srbije (PKS): www.pks.rs/PrivredaSrbije.aspx?id=13\&p=2\& (access: 03/06/2016) 


\title{
ANALIZA UKUPNOG BROJNOG STANJA PREŽIVARA U BOSNI I HERCEGOVINI, SRBIJI I MAKEDONIJI
}

\author{
Gjoko Bunevski ${ }^{1}$, Marko Lazić ${ }^{2}$, Jelena Nikitović ${ }^{3}$ \\ ${ }^{1}$ Univerzitet Ćirilo i Metodije u Skoplju, Fakultet poljoprivrednih nauka i hrane, \\ Blvd. Aleksandra Makedonskog bb., P.O. Box 297, 1000 Skoplje, \\ Republika Makedonija (e-mail:bunevski@gmail.com) \\ ${ }^{2}$ Univerzitet u Kragujevcu, Agronomski fakultet, Cara Dǔ̌ana 34, 32000 Čačak, \\ Republika Srbija (doktorand,e-mail:msc.lazic@gmail.com) \\ ${ }^{3}$ Univerzitet u Banjoj Luci, Institut za genetičke resurse, Bulevar vojvode Petra \\ Bojovića 1A, 78000 Banja Luka, Republika Srpska, Bosna i Hercegovina \\ (e-mail:jelena.nikitovic@griunibl.rs.ba)
}

\begin{abstract}
Rezime
Cilj ovog rada je da se predstavi ukupno brojno stanje nekih preživara $\mathrm{u}$ posljednjih nekoliko godina (od 2007. do 2014. godine) na teritoriji Bosne i Hercegovine, Srbije i Makedonije. Analiza ukupnog brojnog stanja goveda, koza i ovaca je izvršena na osnovu informacija koje su dostupne na web stranici statističke baze podataka FAOSTAT. Za statističku analizu korišćeni su opštepoznati bazni indeksi koji pokazuju promjenu postotaka između godišnjeg i prosječnog brojnog stanja u analiziranom razdoblju. Upoređujući prosjek broja goveda, koza i ovaca u analiziranom razdoblju, može se vidjeti da su navedeni preživari najbrojniji na teritoriji Srbije. Po broju goveda i ovaca sljedeća je Bosna i Hercegovina, a po broju koza Makedonija. S obzirom na dobijeni rezultat, test najmanje značajne razlike pokazuje da su razlike između Makedonije i Bosne i Hercegovine za ukupno brojno stanje koza u razdoblju od 2007. do 2014. godine statistički nesignifikantne $(p>0,001)$.
\end{abstract}

Ključne riječi: bazni indeksi, goveda, koze, ovce. 